\title{
TIPOLOGI DESA BERDASARKAN VARIABEL PENCIRI HUTAN RAKYAT
}

\author{
Village Typologies Analysis Based on Characteristic Variables of Private Forest \\ Tien Lastini ${ }^{1}$, Endang Suhendang ${ }^{2}$, I Nengah Surati Jaya ${ }^{2}$, \\ Hardjanto ${ }^{2}$, dan/and Herry Purnomo ${ }^{2}$ \\ ${ }^{1}$ Program Studi Ilmu Pengetahuan Kehutanan, Sekolah Pascasarjana IPB. \\ Kampus IPB Darmaga, Bogor, Jawa Barat \\ Telp. (0251) 8622642, email : tien_unw@yahoo.com \\ ${ }^{2}$ Fakultas Kehutanan Institut Pertanian Bogor \\ Jl. Raya Darmaga Kampus IPB Darmaga, Bogor 16680 Jawa Barat-Indonesia \\ Telp (0251)8622642 \\ Naskah masuk : 11 Februari 2011; Naskah diterima : 10 Juni 2011
}

\begin{abstract}
The study examined the use of biophysical and socio-economic factors to classify village as characteristic variables of private forest. The main objective of this study is to determine the most significant variables that affect the village typologies related to private forest area. This study was conducted in Kabupaten Ciamis covering 363 villages. There are six of biophysical factors i.e., non rice field-land use, road density, distance to state forest area, distance to main road, land capacity, land configuration; and three of socio-economic factors i.e., population density, permanent home, and productive age population were investigated. The study found that most of those factors has close correlation with the existence of private forest. The only factor that has no correlation with private forest area is distance to main road. Clustering analysis of the study found two typologies of private forest development, namely high potential area and low potential area types. Selected variables for clustering are based on the principle component analysis design of eight correlated variables, with having overall accuracy of $64 \%$.
\end{abstract}

Keywords: Biophysical, clustering analysis, private forest, socio-economic, village typologies

\begin{abstract}
ABSTRAK
Penelitian ini menguji penggunaan faktor biofisik dan sosial ekonomi dalam mengklasifikasi desa dengan variabel penciri hutan rakyat. Tujuan utama dari penelitian ini adalah menentukan variabel yang paling signifikan yang mempengaruhi tipologi desa yang terkait dengan luas hutan rakyat. Penelitian ini dilakukan di Kabupaten Ciamis menggunakan data 336 desa. Dasar pembuatan tipologi pada penelitian ini adalah faktor biofisik dan sosial ekonomi. Terdapat 6 variabel biofisik yaitu: penggunaan lahan non sawah, kelerengan lahan, jarak ke kawasan hutan negara, jarak ke jalan besar, kemampuan lahan, dan kerapatan jalan dan dan 3 variabel sosial ekonomi yaitu: kepadatan penduduk, rumah permanen, dan umur produktif penduduk yang diteliti. Hasil penelitian menemukan terdapat delapan variabel yang berkorelasi, dan satu variabel yang tidak berkorelasi dengan luas hutan rakyat yaitu jarak ke jalan besar. Berdasarkan analisis gerombol, penelitian berhasil menemukan 2 tipologi hutan rakyat, yaitu wilayah yang berpotensi tinggi dan berpotensi rendah untuk berkembangnya hutan rakyat. Variabel yang terpilih untuk penggerombolan adalah berdasarkan desain hasil analisis komponen utama terhadap 8 variabel yang berkorelasi, dengan nilai akurasi umum sebesar $64 \%$.
\end{abstract}

Kata kunci : Biofisik, analisis gerombol, hutan rakyat, sosial ekonomi, tipologi desa 


\section{PENDAHULUAN}

\section{A. Latar Belakang}

Hutan rakyat memiliki karakteristik yang unik. Secara spasial hutan rakyat umumnya tidak tersebar dalam suatu hamparan yang kompak. Luasan kepemilikan relatif kecil sehingga untuk mencapai luasan yang besar maka perlu penggabungan beberapa kepemilikan lahan. Di Pulau Jawa rata-rata kepemilikan dalam satu hamparan sempit kurang dari 1 ha, sehingga sulit untuk mencapai luasan minimum 0,25 ha (Suharjito 2000 dan Haeruman et al. 1991). Luas 0,25 ha sampai saat ini dipakai sebagai syarat untuk dikategorikan sebagai hutan. Sangat berbeda dengan kondisi di luar Indonesia seperti negara-negara Eropa Utara (Filandia, Swedia, dan Norwegia), dimana luasan lahan kepemilikan berkisar antara 5-40 ha per keluarga (Harrison et al. 2002).

Pengelolaan hutan rakyat dilakukan oleh masyarakat secara individual (pada tingkat keluarga) pada lahan miliknya, yang menyebabkan hutan rakyat tidak mengelompok pada suatu areal tertentu tetapi tersebar berdasarkan letak, luas pemilikan lahan dan keragaman pola usaha tani yang akan berpengaruh terhadap jumlah pohon pada setiap kepemilikan. Segala keputusan yang berkaitan dengan pengelolaan hutan rakyat (penanaman, pemeliharaan, penebangan dan pemasaran) ditentukan oleh kebijakan masing-masing keluarga (Mindawati et al., 2006).

Kondisi petani di Indonesia umumnya subsisten, menyebabkan keadaan tersebut menjadikan petani dalam posisi lemah, seperti posisi tawar yang lemah dan informasi yang kurang. Sistem pengelolaan hutan rakyat dengan berdasarkan komponen-komponen yang mendukung dapat menjamin kelestariannya. Dengan demikian untuk menerapkan dan menganalisis komponen-komponen kelangsungan pelestarian itu perlu dibuat suatu perencanaan wilayah berbentuk suatu wadah atau unit pengelolaan. Perencanaan wilayah tersebut sebaiknya bersifat spesifik dengan mempertimbangkan karakteristik wilayah yang dihadapi. Pembentukan unit pengelolaan hutan rakyat memerlukan penggalian karakteristikkarakteristik wilayah yang ingin dikelola, pengelompokan berdasarkan karakteristik tertentu disebut dengan tipologi. Dengan terbentuknya tipologi hutan rakyat diharapkan dapat menentukan arah pengembangan pengelolaan hutan rakyat suatu wilayah yang unik berdasarkan karakteristik masingmasing wilayahnya. Selain itu, tipologi ini dapat membantu menduga potensi sebaran hutan rakyat untuk wilayah yang belum diketahui dan belum dilakukan inventarisasi menyeluruh.

\section{B. Tujuan Penelitian}

Penelitian ini bertujuan menemukan faktor-faktor biofisik dan sosial ekonomi yang membentuk tipologi untuk menduga potensi hutan rakyat.

\section{BAHAN DAN METODE}

\section{A. Waktu dan Lokasi Penelitian}

Penelitian ini dilaksanakan di Kabupaten Ciamis Provinsi Jawa Barat yang mencakup sebanyak 336 desa, dimulai bulan November 2010 sampai dengan Januari 2011. Kabupaten Ciamis memiliki potensi hutan rakyat yang besar di Jawa Barat. 


\section{B. Bahan dan Alat}

Bahan yang digunakan dalam penelitian ini adalah : peta digital administrasi Kabupaten Ciamis, peta digital kontur, peta digital jaringan jalan, peta digital jenis tanah, peta digital kawasan hutan negara (sumber RBI tahun 2006 dan Baplan 2011), data profil desa Kabupaten Ciamis tahun 2006. Alat yang digunakan dalam penelitian ini adalah Arc View versi 3.2, SPSS versi 17 , Minitab versi 14, dan alat pendukung lainnya.

\section{Metode}

\section{Pengumpulan Data}

a. Data sekunder diperoleh dari publikasi lembaga pemerintahan seperti Dinas Kehutanan, Badan Pelaksana Penyuluhan Pertanian Peternakan dan Kehutanan (BP4K), Kementerian Kehutanan, BPS, lembaga penelitian, perguruan tinggi, serta literatur publikasi ilmiah lainnya.

b. Data dan informasi atas hasil analisis pengolahan spasial peta dijital lokasi penelitian dibantu dengan beberapa layer yang mendukung, yaitu peta kontur, peta jaringan jalan, peta kawasan hutan negara, peta tanah, dan peta batas administrasi.

\section{Analisis Data}

\subsection{Identifikasi Variabel-Variabel Pendukung Keberadaan Hutan Rakyat}

Dalam penelitian ini dicari variabelvariabel yang sangat mempengaruhi keberadaan hutan rakyat di suatu lokasi, dengan unit analisisnya adalah desa. Berdasarkan hasil penelusuran pustaka yang terkait dengan hutan rakyat dan pengaruh biofisik terhadap perkembangan suatu wilayah (Suharjito 2000; Awang et al., 2007; Haeruman et al., 1991; Hardjanto 2003) ditemui variabel-variabel sebagai berikut: a. Jarak Terdekat Desa ke Jalan Besar

Jarak terdekat ini didefinisikan sebagai jarak lurus $(\mathrm{km})$ dari batas desa terhadap jalan besar terdekat. Pada penelitian ini yang dimaksud jalan besar adalah jalan kolektor. Jalan kolektor yaitu jalan yang menghubungkan ibukota provinsi dengan ibukota kabupaten atau kotamadya terhadap kepentingan provinsi. Perhitungan jarak dilakukan dengan analisis spasial.

b. Jarak Terdekat Desa ke Kawasan Hutan Negara Terdekat.

Jarak terdekat ini didefinisikan sebagai jarak lurus $(\mathrm{km})$ dari batas desa terhadap kawasan batas hutan negara terdekat. Kedekatan terhadap kawasan hutan negara memiliki peluang untuk berkembangnya hutan rakyat baik secara alam maupun budaya. Perhitungan jarak terdekat tersebut menggunakan analisis spasial terhadap 2 layer, yaitu layer batas administrasi desa dengan batas kawasan hutan negara di Kabupaten Ciamis.

c. Rasio Kelerengan Lahan

Menurut Awang et al., (2001) menyatakan salah satu areal yang menjadi sasaran pembangunan hutan rakyat adalah areal kritis dengan keadaaan lapangan berjurang dan bertebing. Sehingga variabel yang perlu diperhatikan adalah perbandingan (rasio) antar luas areal dengan kelas kelerengan lahan yang lebih besar sama dengan $15 \%$ terhadap total luas desa. Pendekatan yang digunakan dalam penelitian ini adalah kelas lereng yang sudah umum digunakan dalam penatagunaan hutan. Kelas-kelas kelerengan dalam suatu wilayah dapat dilihat pada Tabel 1 .

Tabel (Table) 1. Klasifikasi kelas lereng (Clasification of slope classes)

\begin{tabular}{|c|c|c|}
\hline No. & $\begin{array}{c}\text { Kelas lereng } \\
\text { (Slope classes) }\end{array}$ & $\begin{array}{c}\text { Kisaran } \\
(\text { Intervals }) \\
(\%)\end{array}$ \\
\hline 1 & Datar & $0-8$ \\
2 & Landai & $8-15$ \\
3 & Agak Curam & $15-25$ \\
4 & Curam & $25-40$ \\
5 & Sangat Curam & $>40$ \\
\hline
\end{tabular}


d. Penggunaan Lahan Bukan Sawah (Non Sawah)

Penggunaan lahan bukan sawah adalah perbandingan (rasio) areal lahan pertanian non sawah dengan luas total desa. Dari beberapa penelitian yang telah dilakukan menyatakan bahwa hutan rakyat di Jawa umumnya dibudidayakan di areal-areal lahan kering daerah atas (upland areas).

e. Kerapatan Jalan

Kerapatan jalan adalah rasio antara luas jalan (m) dengan luas desa(ha). Rumusnya dapat dilihat sebagai berikut:

Kerapatan Jalan $\frac{\text { Panjang jalan }(\mathrm{m})}{\text { Luas desa (ha) }}$

f. Kemampuan Lahan

Hutan rakyat di Jawa umumnya banyak ditanam di wilayah lahan kritis yang tidak subur, sehingga diduga ada hubungan antara potensi hutan rakyat dengan kondisi kemampuan lahannya. Kemampuan lahan dalam penelitian ini ditentukan berdasarkan faktor-faktor yang dipertimbangkan untuk membuat modifikasi kelas kemampuan lahan adalah kelerengan, kepekaan erosi, kedalaman tanah, tekstur tanah permeabilitas, dan drainase di suatu wilayah desa. Adapun variabel kemampuan lahan di suatu desa (KL) (Arsyad, 1989):

$$
K L=\frac{\sum_{i=1}^{8} L_{i} \times N t_{i}}{\text { Luas Total Desa }}
$$

Dimana :

$\mathrm{Li}=$ Luas kemampuan lahan kelas ke- $\mathrm{i}$ $(\mathrm{i}=1,2,3 \ldots .8)$

NTi $=$ Nilai Tengah kelas ke- $\mathrm{i}(\mathrm{i}=1$, $2,3 \ldots .8)$ g. Kepadatan Penduduk

Kepadatan penduduk didefinisikan sebagai rasio antara jumlah penduduk di setiap desa (orang) dengan luas administratif desa (ha). Umumnya hutan rakyat timbul pada wilayah-wilayah yang masih kurang padat penduduknya.

\section{H. Rasio Umur Produktif}

Rasio umur produktif adalah perbandingan antara jumlah penduduk berusia produktif (15 - 64 tahun) dengan luas total desa. Pengelolaan hutan rakyat masih dianggap kegiatan sampingan yang bersifat tidak intensif, sehingga diduga beberapa wilayah yang berkembang hutan rakyatnya ketika jumlah umur produktif sedikit dan didominasi umur non produktif.

\section{f. Rasio Rumah Permanen}

Rasio rumah permanen merupakan pendekatan terhadap informasi pendapatan penduduk. Diasumsikan bahwa ketika pendapatan penduduk semakin meningkat maka kondisi rumahnya akan semakin permanen. Untuk data pendapatan dilakukan dengan pendekatan terhadap kondisi perumahan, yaitu dari rasio antara jumlah rumah permanen dengan total rumah di desa bersangkutan. Semakin besar rasio maka diasumsikan pendapatan penduduk setempat semakin tinggi.

Sehingga secara keseluruhan ada 9 (sembilan) variabel yang diuji untuk mengetahui yang berpengaruh terhadp pembagian tipologi. Secara ringkas variabel-variabel tersebut dapat dilihat pada Tabel 2 .

Tabel (Table) 2. Variabel-variabel tipologi hutan rakyat (Typology Variables of private forest)

\begin{tabular}{|l|l|l|}
\hline No. & \multicolumn{1}{|c|}{$\begin{array}{c}\text { Indikator } \\
\text { (Indicators })\end{array}$} & \multicolumn{1}{c|}{$\begin{array}{c}\text { Peubah-Peubah } \\
\text { (Variables })\end{array}$} \\
\hline 1. & Karakteristik Bio-Fisik & - Jarak ke kawasan hutan hutan negara \\
& & - Jarak ke jalan besar \\
& & - Kemampuan Lahan \\
& & - Rasio kelerengan lahan \\
& & - Penggunan Lahan (land use) \\
& & - Kerapatan jaringan jalan \\
& & \\
2. & Karakteristik Sosial dan & - Kepadatan penduduk \\
& Ekonomi & - Tingkat rumah permanen \\
& & - Rasio Umur produktif penduduk \\
\hline
\end{tabular}




\subsection{Penentuan Variabel Dominan}

Dari 9 (sembilan) variabel akan dianalisis hubungannya dengan hutan rakyat di suatu desa. Potensi hutan rakyat dalam penelitian ini adalah luas hutan rakyat di suatu desa. Untuk menganalisis hal tersebut digunakan 2 cara, yaitu :

\section{a. Analisis Korelasi}

Pada penelitian ini, analisi korelasi menghubungkan 2 variabel yaitu masing-masing 9 variabel biofisik dan sosial ekonomi yang diuji dengan luas hutan rakyat di suatu desa. Analisis korelasi yang di-gunakan adalah korelasi Spearman. Nilai - 1 atau +1 menunjukkan adanya hubungan yang sempurna antara $X$ dan $\mathrm{Y}$, sehingga semakin mendekati nilai tersebut semakin erat hubungan $\mathrm{X}$ dan $\mathrm{Y}$.

\section{b. Analisis Komponen Utama (Principal} Component Analysis/PCA)

Tujuan dari analisis komponen utama dalam penelitian ini, yaitu:

(1) untuk mendapatkan variabel-variabel baru yang saling orthogonal/bebas, dan mereduksi objek dalam dimensi yang lebih kecil.

(2) mengelompokkan variabel-variabel penting dari satu bundel variabel besar untuk menduga suatu fenomena, sekaligus memahami struktur dan melihat hubungan antar variabel.

Ada tiga karakteristik komponen utama: informasi data asal yang dijelaskan maksimum (memiliki ragam maksimum), antar komponen utama saling original/bebas, merupakan konbinasi linier dari variabel asal:

$$
Y_{i}=a_{i 1} X_{1}+a_{i 2} X_{2}+\ldots+a_{i p} X_{p}
$$

Hasil analisis komponenkomponen utama antara lain nilai akar ciri, proporsi, dan kumulatif akar ciri.

\subsection{Pembentukan Tipologi}

a. Penggunaan Analisis Gerombol (Clustering Analysis)

Dasar pembuatan tipologi adalah variabelvariabel yang dianggap dominan dalam menentukan potensi hutan rakyat. Potensi hutan rakyat dalam penelitian ini adalah luas hutan rakyat di suatu desa. Diasumsikan bahwa potensi tersebut dapat mewakili karakteristik lokal hutan rakyat di suatu tempat. Untuk melakukan pengelompokan tipologi digunakan analisis gerombol (clustering analysis). Penelitian ini menggunakan analisis gerombol ini dengan metode K-Means, metode ini menetapkan terlebih dahulu jumlah kelompok yang akan dibuat sehingga metode ini cocok jika data yang diolah banyak. Penggunaan metode ini banyak digunakan untuk beberapa tujuan penelitian (Rahmalia 2003).

b. Pengujian Tipologi

Untuk mengetahui kelompok-kelompok yang terbentuk sudah memiliki gambaran yang mirip terhadap potensi hutan rakyat, maka dilakukan pengujian sebagai berikut :

(1) Uji keragaman

Kelompok yang terbentuk dikatakan baik jika keragaman dalam satu kelompok kecil, tetapi keragaman antar kelompok besar. Sehingga dilakukan pengujian pada setiap kelompok yang sudah terbentuk. Keragaman dapat diketahui dengan rumus :

Ragam rata-rata dalam kelompok adalah :

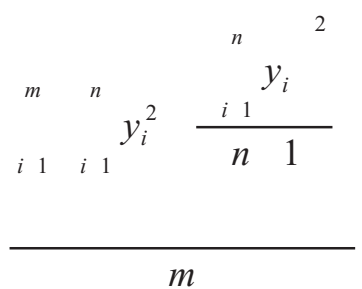

Keterangan :

$\mathrm{yi}=$ luas hutan rakyat pada desa ke-i

$\mathrm{n}=$ jumlah desa pada kelompok ke-i

$\mathrm{m}=$ jumlah kelompok

Ragam antar kelompok yang distandarkan :

$$
s_{i j}^{2}=\left|\frac{\sum s_{i}^{2}-s_{j}^{2}}{s_{\bar{y}}^{2}}\right|
$$

Keputusan yang terbaik jika: memiliki ragam dalam kelompok yang terkecil dan ragam antar kelompok yang terbesar. Sehingga jika mencari gabungan yang terbaik adalah yang memiliki selisih ragam antar kelompok dengan ragam dalam kelompok yang terbesar.

(2) Evaluasi akurasi

Untuk menguji akurasi kelompok yang terbentuk menggunakan prinsip matrik kesalahan (confusion matrix). Sebagai 
standar adalah kelompok yang dibentuk berdasarkan data luas hutan rakyat. Dari confusion matrix dapat menghitung akurasi rata-rata umum (overall accuracy) dan akurasi kappa accuracy. Akurasi rata-rata umum dihitung menggunakan rumus (Jaya, 2006) sebagai berikut :

$$
O A=\left[\frac{\sum_{i=1}^{r} X_{i i}}{N} \times 100 \%\right]
$$

Keterangan (Remarks) :

$\mathrm{OA}=$ Nilai akurasi rata-rata umum (Overall Accuracy)

$\mathrm{X}_{\mathrm{ii}}=$ Coincided Value atau luasan kelas tingkat keberhasilan yang sama antar kelompok atau kelompok variabel yang dijadikan acuan untuk verifikasi.

$\mathrm{N}=$ Total area verifikasi.

Akurasi kappa pada umumnya mempunyai nilai akurasi lebih kecil dari akurasi rata-rata umum karena pada akurasi kappa dihitung tidak hanya berdasarkan jumlah desa yang dikelaskan masuk secara benar pada kelas acuan, tetapi juga menghitung jumlah desa yang dikelaskan pada tipologi tidak tepat masuk dalam kelas acuan. Akurasi kappa dihitung menggunakan rumus (Jaya, 2006) sebagai berikut:

$$
K=\frac{N \sum_{i=1}^{r} X_{i i}-\sum_{i=1}^{r} X_{i+} X_{+1}}{N^{2}-\sum_{i=1}^{r} X_{i+} X_{+1}} \times 100 \%
$$

Keterangan (Remarks) :

$\mathrm{K}=$ Akurasi Kappa (Kappa Accuracy)

Xii = Coincided Value atau luasan kelas tingkat keberhasilan yang sama antara hasil tipologi dan kelas variabel yang dijadikan acuan untuk verifikasi.

$\mathrm{X}+1=$ Luas kolom dalam baris ke- $\mathrm{i}$

$\mathrm{X} 1+=$ Luasan dalam kolom ke-j

$\mathrm{N}=$ Total area verifikasi

\section{HASIL DAN PEMBAHASAN}

\section{A. Penentuan Variabel Dominan Pembentuk Tipologi}

Berdasarkan korelasi Spearman terdapat hubungan yang sangat nyata antara beberapa variabel terhadap keberadaan luas hutan rakyat di suatu desa, dapat dilihat pada Tabel 3. Korelasi sangat nyata yang bersifat positif saling menguatkan adalah : rasio penggunaan lahan bukan sawah (non sawah), dan rasio kelerengan lahan. Sedangkan korelasi sangat nyata yang bersifat negatif adalah kepadatan penduduk, pendapatan penduduk, umur produktif, jarak ke hutan, kemampuan lahan, dan kerapatan jalan. Dari 9 peubah tersebut yang memiliki nilai tiga terbesar korelasinya adalah rasio kelerengan lahan, kerapatan jalan, dan rasio lahan bukan sawah. Sedangkan yang tidak berkorelasi adalah jarak desa ke jalan besar terdekat.

Tabel (Table) 3. Korelasi antar variabel biofisik, sosial ekonomi, dan luas hutan rakyat (The correlation

\begin{tabular}{|c|c|c|c|c|c|c|c|c|c|c|}
\hline $\begin{array}{r}\text { Variabel } \\
\text { (Variables) }\end{array}$ & $\begin{array}{c}\text { Luas } \\
\text { Hutan } \\
\text { rakyat } \\
\text { (Private } \\
\text { forest } \\
\text { area) }\end{array}$ & $\begin{array}{c}\text { Kepadatan } \\
\text { Penduduk } \\
\text { (Population } \\
\text { density) }\end{array}$ & $\begin{array}{c}\text { Rumah } \\
\text { Permanenen } \\
\text { (Permanent } \\
\text { home })\end{array}$ & $\begin{array}{l}\text { Umur } \\
\text { Produktif } \\
\text { (Producti- } \\
\text { ve age } \\
\text { populati- } \\
\text { on) }\end{array}$ & $\begin{array}{l}\text { Non } \\
\text { Sawah } \\
\text { (Non rice } \\
\text { field) }\end{array}$ & $\begin{array}{l}\text { Kelere- } \\
\text { ngan } \\
\text { lahan } \\
\text { (Land } \\
\text { slope) }\end{array}$ & $\begin{array}{l}\text { Jarak } \\
\text { Hutan } \\
\text { (Distance } \\
\text { to state } \\
\text { forest } \\
\text { area) }\end{array}$ & $\begin{array}{l}\text { Jarak } \\
\text { Jalan } \\
\text { (Distan- } \\
\text { ce to } \\
\text { main } \\
\text { road }) \\
\end{array}$ & $\begin{array}{l}\text { Kemam- } \\
\text { puan } \\
\text { Lahan } \\
\text { (Land } \\
\text { capacity) }\end{array}$ & $\begin{array}{c}\text { KerapatnJ } \\
\text { alan (Road } \\
\text { density) }\end{array}$ \\
\hline $\begin{array}{l}\text { Luas Hutan Rakyat } \\
\text { (Private forest area) }\end{array}$ & 1.000 & $-.357^{* *}$ & $-.197^{* \prime \prime}$ & $-380^{* \prime \prime}$ & $.441^{* *}$ & $.529^{* \prime \prime}$ & $-.426^{\prime \prime}$ & .099 & $-.233^{* \prime \prime}$ & $-.496^{\prime \prime \prime}$ \\
\hline $\begin{array}{l}\text { Kepadatan } \\
\text { Pendudu } \\
\text { (population density) }\end{array}$ & $-.357^{\circ 7}$ & 1.000 & $.208^{\prime \prime \prime}$ & $.932^{* \pi}$ & $-.297^{\prime \prime \prime}$ & $-.277^{n+1}$ & $.225^{* 1 *}$ & $-.154^{\prime \prime \prime}$ & .058 & $.453^{\prime \prime \prime}$ \\
\hline $\begin{array}{l}\text { Rumah Permanen } \\
\text { (Permanent home) }\end{array}$ & $-.197^{2 \pi}$ & $.208^{2 *}$ & 1.000 & $.245^{* *}$ & $-.111^{*}$ & -.050 & .101 & -.072 & -.045 & $.234^{2 * *}$ \\
\hline $\begin{array}{l}\text { Umur Prod uktif } \\
\text { (Productive age } \\
\text { population) }\end{array}$ & $-380^{* 2 *}$ & $.932^{* *+4}$ & $.245^{\circ " 7}$ & 1.000 & $-265^{* * *}$ & $-.264^{* * *}$ & $.216^{* * *}$ & $-.178^{* * *}$ & .072 & $.447^{* * *}$ \\
\hline $\begin{array}{l}\text { Non Swh (Non rice } \\
\text { field) }\end{array}$ & $.441^{\prime \prime \prime}$ & $-.297^{m *}$ & $-.111^{*}$ & $-.265^{\mathrm{mm}}$ & 1.000 & $.486 "$ & $-.215^{\circ 7}$ & $.167^{\circ "}$ & $-.266^{\circ 2}$ & $-367^{m m}$ \\
\hline $\begin{array}{l}\text { Kelerengan } \\
\text { lahan(Land slope) }\end{array}$ & $.529^{* * \pi}$ & $-.277^{* *}$ & -.050 & $-.264^{* * *}$ & $.486^{* *}$ & 1.000 & $-.565^{2 *}$ & $.139^{*}$ & $-.433^{* 2 *}$ & $-.382^{* *}$ \\
\hline $\begin{array}{l}\text { Jarak hutan } \\
\text { (Distance to state } \\
\text { forest area) }\end{array}$ & $-.426^{2 n}$ & $.225^{* * 4}$ & .101 & $.216^{* *}$ & $-.215^{* * *}$ & $-.565^{* *+}$ & 1.000 & $-.108^{*}$ & $.2766^{* * \pi}$ & $.320^{* * *}$ \\
\hline $\begin{array}{l}\text { Jarak Jalan } \\
\text { (Distance to main } \\
\text { road) }\end{array}$ & .099 & $-.154^{\prime \prime \prime}$ & -.072 & $-.178^{* \prime \prime \prime}$ & $.167^{* 17}$ & $.139^{\prime \prime}$ & $-.108^{*}$ & 1.000 & $-.145^{\prime \prime \prime}$ & $-.198^{m * \prime}$ \\
\hline $\begin{array}{l}\text { KmampuanLahan } \\
\text { (Land capacity) }\end{array}$ & $-.233^{* 2}$ & .058 & -.045 & .072 & $-.266^{* * \pi}$ & $-.433^{* *}$ & $.276^{* *}$ & $-.145^{* *}$ & 1.000 & $.127^{*}$ \\
\hline $\begin{array}{l}\text { Kerapatan J alan } \\
\text { (Road density) }\end{array}$ & $-.496^{2 *}$ & $.453^{* *}$ & $.234^{* * *}$ & $.447^{* 1+1}$ & $-.367^{2 * 1}$ & $-.382^{2 * 2}$ & $.320^{2 *}$ & $-.198^{* * *}$ & $.127^{*}$ & 1.000 \\
\hline
\end{tabular}
between biophysical and socio-economic variables and private forest area)

Keterangan (Remarks): ** Berkorelasi nyata pada level 0,01 (Correlated at 0,01 level)

* Berkorelasi nyata pada level 0,05 (Correlated at 0,05 level) 
Penjelasan lebih terperinci mengenai kondisi antara variabel-variabel tersebut sebagai berikut:

a. Kepadatan Penduduk

Merupakan variabel yang berhubungan negatif dengan luas hutan rakyat. Hutan rakyat umumnya ditemukan pada wilayah berpenduduk rendah. Secara logis hal ini tentu demikian, kerena semakin sedikit penduduk berpeluang areal digunakan dengan penggunaan lain selain pemukiman seperti perkebunan dan lainnya. Kepadatan penduduk juga berkorelasi positif dengan variabel rasio umur produktif, sehingga semakin padat penduduk kemungkinan besar jumlah umur produktif juga ikut bertambah di suatu wilayah desa.

b. Rasio rumah permanen

Keberadaaan rumah permanen dalam penelitian ini diasumsikan dengan pendapatan penduduk. Hubungan antar pendapatan penduduk dengan potensi keberadaan hutan rakyat di suatu desa berkorelasi negatif. Hutan rakyat umumnya banyak ditemukan pada kondisi desa yang memiliki rata-rata pendapatan yang rendah. Hal ini disebabkan timbulnya hutan rakyat pada kondisi lahan marginal yang tidak memiliki banyak alternatif kegiatan pertanian yang lebih produktif.

c. Rasio Umur Produktif

Pengelolaan hutan rakyat tidak seintensif pengelolaaan pertanian dan perkebunan. Sehingga ketika terjadi urbanisasi yang besar, banyak penduduk desa yang berada dalam usia produktif bekerja di kota. Akhirnya kebanyakan penduduk yang tinggal di desa adalah orang-orang usia lanjut. Kondisi ini mendorong pemilihan menanam kayukayuan dibanding dengan pertanian intensif. Sehingga hubungan korelasi antara rasio umur produktif dengan luas hutan rakyat bersifat negatif.

d. Kerapatan Jalan

Variabel ini berkorelasi dominan kedua setelah rasio kelerengan lahan terhadap keberadaan hutan rakyat di suatu desa. Ketika desa memiliki kerapatan jalan yang besar cenderung memiliki hutan rakyat yang sedikit. Kerapatan jalan berhubungan dengan kemajuan transportasi di suatu wilayah desa. Semakin maju desa memungkinkan banyaknya alternatif penggunaan lahan lain yang lebih produktif. e. Rasio Penggunaan Lahan Bukan Sawah (Non sawah)

Berdasarkan penelitian Suharjito (2000), menyatakan umumnya lokasi hutan rakyat berada di wilayah areal lahan kering daerah atas (upland areas). Daerah tersebut merupakan daerah pertanian non sawah, yang biasa disebut dengan tegalan atau kebun. Lahan ini dalam pendataan statistik disebut dengan lahan pertanian non sawah. Dari hasil korelasi menunjukkan bahwa variabel ini berhubungan positif dengan keberadaan hutan rakyat dan sangat nyata hubungannya. Ini menenjukkan bahwa variabel rasio non sawah bisa menjadi penanda untuk menduga potensi pengembangan hutan rakyat di suatu desa atau wilayah. Semakin luas penggunaan lahan pertanian non sawah berarti semakin besar pula potensi pengembangan hutan rakyatnya.

f. Kemampuan lahan

Berdasarkan pengalaman sejarah dimulainya hutan rakyat karena gerakan penghijauan pada daerah-daerah kritis (Hardjanto 2003). Sehingga sekarang diduga tumbuhnya hutan rakyat dominan di wilayah-wilayah tidak subur. Hasil korelasi dengan luas hutan rakyat menunjukkan adanya korelasi negatif berarti hutan rakyat memang cenderung berkembang pada wilayah-wilayah dengan kemampuan lahan yang rendah.

g. Rasio kelerengan lahan

Variabel ini memiliki korelasi tertinggi diantara variabel lainnya. Ini menunjukkan bahwa hutan rakyat dominan berada di wilayah yang tidak datar, yakni berada di wilayah landai sampai curam. Hutan rakyat merupakan alternatif berikutnya ketika lahan tidak memungkinkan untuk ditanam tanaman pertanian atau budidaya lain yang lebih cepat menghasilkan. Wilayah yang tidak memperoleh pengairan untuk sawah berada di wilayah-wilayah atas (upland areas) yang tentunya memiliki topografi lebih curam, di sinilah hutan rakyat berkembang.

h. Jarak ke Hutan Negara

Keberadaan hutan negara di dalam atau sekitar desa ternyata berpengaruh dengan keberadaaan hutan rakyat. Semakin dekat areal hutan negara dengan suatu desa, maka umumnya semakin besar potensi hutan rakyat. Kondisi ini diduga karena Variabel biofisik dan budaya. Wilayah hutan negara di Kabupaten Ciamis umumnya berada di lokasi topografi curam di daerah-daerah pegunung- 
an dengan kondisi assesibilitas yang sulit. Memperhatikan kondisi biofisik tersebut, maka alternatif penggunaan lahan untuk penanaman tidak banyak dengan demikian menanam kayu yang bersifat tidak intensif menjadi pilihan, sedangkan dipandang dari sudut budaya, diduga karena berdekatan dengan hutan sejak dulu, maka masyarakat sekitar hutan sudah terbiasa dengan pengelolaan hutan dan malah juga terlibat langsung sebagai penggarap jika hutan tersebut hutan produksi. Sebagai penggarap di areal tumpangsari PT Perhutani, maka petani sudah terbiasa dengan cara-cara menanam, memelihara, dan bahkan terlibat dalam ke-giatan pemanenan sebagai buruh tebang. Dengan demikian kebiasaan ini dapat tertular di lahan milik pribadi mereka. Ditambah dengan seringkali penyebaran bibit secara alam dari hutan negara ke lahan milik melalui angin dan binatang-binatang hutan. Sehingga tumbuhlah jenis-jenis tanaman yang biasa ada di hutan negara seperti jati, mahoni, dan pinus di lahan milik pribadi petani.

i. Jarak ke jalan

Analisis korelasi jarak terdekat antar batas desa ke jalan besar (jalan kolektor) ternyata tidak berpengaruh nyata terhadap kondisi hutan rakyat di suatu desa dibanding variabel lainnya. Jalan besar merupakan jalur transportasi pengangkutan kayu ke luar wilayah. Ketika variabel ini tidak nyata berpengaruh terhadap luas hutan rakyat, kemungkinan setiap lokasi memiliki keuntungan yang seimbang terhadap perkembangan hutan rakyat. Wilayah dekat jalan besar memiliki keuntungan biaya pengangkutan menjadi murah tetapi tentu harga tanah yang lebih mahal, sedangkan wilayah jauh dari jalan besar sebaiknya.

Berdasarkan analisis komponen utama (PCA) yaitu variabel-variabel yang berhubungan nyata dengan luas hutan rakyat di suatu desa. Dari hasil korelasi pada Tabel 3 diketahui bahwa dari 9 variabel yang dianalisis, hanya satu variabel yaitu jarak ke jalan besar yang tidak signifikan berkorelasi nyata. Sehingga untuk analisis komponen utama dimasukkan 8 variabel pendukung. Untuk mengetahui berapa banyak komponen utama (KU) yang diambil, maka dapat dilihat dari nilai kumulatif proporsi lebih dari $70 \%$ dan nilai akar ciri lebih besar dari 0,7, sehingga dari delapan komponen utama yang dihasilkan dapat dipotong sampai KU empat saja karena sudah cukup mewakili proporsi keragaman.

Tabel(Table) 4. Nilai analisis komponen utama variabel (Value of principal component analysis)

\begin{tabular}{|c|c|c|c|c|c|c|c|c|c|}
\hline No & Variabel (Variables) & $\mathrm{PC} 1$ & $\mathrm{PC} 2$ & $\mathrm{PC} 3$ & PC4 & PC5 & PC6 & PC7 & PC8 \\
\hline 1. & $\begin{array}{l}\text { Kepadatan Penduduk } \\
\text { (Population density) }\end{array}$ & 0,340 & $\begin{array}{c}- \\
0,389\end{array}$ & $\begin{array}{c}- \\
0,523\end{array}$ & 0,115 & $-0,056$ & 0,033 & $-0,627$ & 0,223 \\
\hline 2. & $\begin{array}{l}\text { Rumah permanen } \\
\text { (Permanent home) }\end{array}$ & 0,146 & $\begin{array}{c}- \\
0,340\end{array}$ & 0,603 & $-0,108$ & $-0,669$ & 0,056 & $-0,114$ & 0,156 \\
\hline 3. & $\begin{array}{l}\text { Umur Produktif } \\
\text { (Productive age } \\
\text { population) }\end{array}$ & 0,371 & $\begin{array}{c}- \\
0,479\end{array}$ & $\begin{array}{c}- \\
0,284\end{array}$ & 0,107 & $-0,133$ & $-0,083$ & 0,668 & $-0,264$ \\
\hline 4 & $\begin{array}{l}\text { Non Sawah } \\
\text { (Non rice field) }\end{array}$ & $\begin{array}{c}- \\
0,441\end{array}$ & $\begin{array}{c}- \\
0,185\end{array}$ & $\begin{array}{c}- \\
0,018\end{array}$ & 0,457 & $-0,080$ & $-0,661$ & 0,068 & 0,338 \\
\hline 5. & $\begin{array}{l}\text { Kelerengan lahan } \\
\text { (Land slope) }\end{array}$ & $\begin{array}{c}- \\
0,491\end{array}$ & $\begin{array}{c}- \\
0,295\end{array}$ & $\begin{array}{c}- \\
0,100\end{array}$ & $-0,168$ & $-0,149$ & $-0,084$ & $-0,281$ & $-0,725$ \\
\hline 6. & $\begin{array}{l}\text { Jarak ke hutan } \\
\text { (Distance to state } \\
\text { forest area) }\end{array}$ & 0,337 & 0,293 & 0,212 & 0,715 & $-0,074$ & $-0,056$ & $-0,199$ & $-0,443$ \\
\hline 7. & $\begin{array}{l}\text { Kemampuan Lahan } \\
\text { (Land capacity) }\end{array}$ & 0,185 & 0,520 & $\begin{array}{c}- \\
0,333\end{array}$ & $-0,325$ & $-0,523$ & $-0,450$ & $-0,001$ & $-0,055$ \\
\hline 8. & $\begin{array}{l}\text { Kerapatan Jalan } \\
\text { (Road density) }\end{array}$ & 0,377 & $\begin{array}{c}- \\
0,164\end{array}$ & 0,341 & $-0,331$ & 0,475 & $-0,582$ & $-0,157$ & $-0,128$ \\
\hline & Akar ciri (eigenvalue) & 2,407 & 1,323 & 1,069 & 0,904 & 0,8463 & 0,5602 & 0,4969 & 0,3929 \\
\hline & Proporsi (proportion) & 0,301 & 0,165 & 0,134 & 0,113 & 0,106 & 0,070 & 0,062 & 0,049 \\
\hline & $\begin{array}{l}\text { Kumulatif Proporsi } \\
\text { (Proportion } \\
\text { cumulative) }\end{array}$ & 0,301 & 0,466 & 0,600 & 0,713 & 0,819 & 0,889 & 0,951 & 1,000 \\
\hline
\end{tabular}


Berdasarkan analisis komponen utama yang menggunakan $4 \mathrm{KU}$ pada Tabel 4 dapat diketahui empat karakteristik desa di Kabupaten Ciamis yang didekati dari 8 Variabel. Karakteristik tersebut dapat dilihat dari variabel dominan yang membentuk komponen utamanya sebagai berikut:

- Pada PC1 menggambarkan indeks kelerengan lahan dan non sawah. Nilai ini menunjukkan dominan kelerengan lahan yang datar dengan kegiatan non persawahan yang rendah.

- Pada Pc2 merupakan indeks kondisi kemampuan lahan. Dimana menujukkan kemampuan lahan yang tinggi.

- Wilayah Pc3 merupakan indeks rumah permanen dan kepadatan penduduk yang merupakan variabel sosial ekonomi.

- Pada wilayah PC4 merupakan indeks jarak desa ke kawasan hutan negara. Dimana menujukkan nilai tinggi pada jarak yang ke kawasan hutan

\section{B. Pembentukan Tipologi}

\section{Jumlah tipologi}

Hasil klustering dengan menggunakan semua alternatif variabel yang bisa diterapkan, yaitu dari penggunaan 8 variabel sampai 2 variabel ditambah dengan penggunaan data analisis komponen utama (AKU) dapat dilihat pada Tabel 5 .

Tabel 5 dapat diketahui bahwa penggunaan 5 kelompok dan 4 kelompok menghasilkan jumlah tipologi yang kurang efisien karena jumlah anggota sangat kecil dibawah 10 desa, kecuali satu yang menggunakan desain PC123 dengan 4 Kelompok. Sedangkan untuk 3 kelompok dan 2 kelompok terdapat 4 desain jumlah variabel yang menghasilkan jumlah kelompok yang efisien, yaitu yang menggunakan desain 2 variabel, 4 variabel, PC1234, dan Pc123.

Tabel(Table) 5. Banyaknya anggota setiap desain dan kelompok (Number of villages each design and cluster)

\begin{tabular}{|c|c|c|c|c|c|c|c|c|c|}
\hline \multicolumn{9}{|c|}{$\begin{array}{l}\text { JUMLAH ANGGOTA TIAP KELOMPOK } \\
\text { (Number of villages of each cluster) }\end{array}$} & \multirow[b]{2}{*}{$\begin{array}{l}\text { PC- } \\
123\end{array}$} \\
\hline $\begin{array}{l}\text { Desain } \\
\text { Jmh } \\
\text { Variabel }\end{array}$ & $\begin{array}{c}8 \\
\text { Variabel }\end{array}$ & $\begin{array}{c}7 \\
\text { Variabel }\end{array}$ & $\begin{array}{c}6 \\
\text { Variabel }\end{array}$ & $\begin{array}{c}5 \\
\text { Variabel }\end{array}$ & $\begin{array}{c}4 \\
\text { Variabel }\end{array}$ & $\begin{array}{c}3 \\
\text { Variabel }\end{array}$ & $\begin{array}{c}2 \\
\text { Variabel }\end{array}$ & $\begin{array}{l}\text { PC- } \\
1234\end{array}$ & \\
\hline \multicolumn{9}{|c|}{$\begin{array}{l}5 \text { Kelompok } \\
\text { (5 clusters) }\end{array}$} & \\
\hline 1 & 183 & 183 & 183 & 183 & 183 & 161 & 161 & 176 & 149 \\
\hline 2 & 86 & 86 & 86 & 86 & 86 & 124 & 124 & 68 & 72 \\
\hline 3 & 62 & 62 & 62 & 62 & 62 & 45 & 45 & 53 & 70 \\
\hline 4 & 2 & 2 & 2 & 2 & 2 & 5 & 5 & 43 & 40 \\
\hline 5 & 3 & 3 & 3 & 3 & 3 & 1 & 1 & 5 & 5 \\
\hline \multicolumn{9}{|c|}{$\begin{array}{l}4 \text { Kelompok } \\
\text { (4 clusters) }\end{array}$} & \\
\hline 1 & 185 & 185 & 185 & 185 & 185 & 171 & 171 & 185 & 153 \\
\hline 2 & 60 & 60 & 60 & 60 & 60 & 115 & 115 & 86 & 85 \\
\hline 3 & 86 & 86 & 86 & 86 & 86 & 44 & 44 & 60 & 61 \\
\hline 4 & 5 & 5 & 5 & 5 & 5 & 6 & 6 & 5 & 37 \\
\hline \multicolumn{9}{|c|}{$\begin{array}{l}\text { 3 Kelompok } \\
\text { (3 clusters) }\end{array}$} & \\
\hline 1 & 228 & 228 & 228 & 228 & 228 & 202 & 202 & 196 & 195 \\
\hline 2 & 103 & 103 & 103 & 103 & 103 & 99 & 99 & 80 & 78 \\
\hline 3 & 5 & 5 & 5 & 5 & 5 & 35 & 35 & 60 & 63 \\
\hline \multicolumn{9}{|c|}{$\begin{array}{l}2 \text { Kelompok } \\
(2 \text { clusters) }\end{array}$} & \\
\hline 1 & 239 & 239 & 239 & 239 & 239 & 249 & 249 & 235 & 234 \\
\hline 2 & 97 & 97 & 97 & 97 & 97 & 87 & 87 & 101 & 102 \\
\hline
\end{tabular}


Tabel (Table) 6. Jumlah desa setiap kelompok terpilih (Number of villages for each selected cluster)

\begin{tabular}{|c|c|c|c|c|}
\hline $\begin{array}{c}\text { Desain Jumlah } \\
\text { Variabel } \\
\text { (Number of variables } \\
\text { Design) }\end{array}$ & $\begin{array}{c}\text { Kelompok 1 } \\
\text { (cluster 1) }\end{array}$ & $\begin{array}{c}\text { Kelompok 2 } \\
\text { (cluster 2) }\end{array}$ & $\begin{array}{c}\text { Kelompok 3 } \\
\text { (cluster 3) }\end{array}$ & $\begin{array}{c}\text { Kelompok 4 } \\
\text { (cluster 4) }\end{array}$ \\
\hline- & 249 & 87 & - & - \\
\hline 2 Variabel -3 Kelp & 202 & 99 & 53 & - \\
\hline 4 Variabel -2 Kelp & 239 & 97 & - & - \\
\hline PC1234 - Kelp & 235 & 101 & - & - \\
\hline PC1234 - 3 Kelp & 196 & 80 & 60 & 37 \\
\hline PC1234 - 4 Kelp & 153 & 85 & 61 & - \\
\hline PC1234 - 3 Kelp & 195 & 78 & 63 & - \\
\hline PC1234 - 2 Kelp & 234 & 102 & - & - \\
\hline
\end{tabular}

Semua desain yang telah dicoba (Tabel 5), hanya 8 desain jumlah variabel yang dapat diterapkan selanjutnya. Desain jumlah variabel yang menghasilkan jumlah kelompok yang sama maka dipilih yang paling sederhana. Daftar desain terpilih tersebut dapat dilihat pada Tabel 6.

\section{Pengujian Hasil Tipologi}

Hasil tipologi yang telah terbentuk dengan berbagai desain peubah diuji ketepatannya untuk menduga luas rakyat setiap desa. Dibandingkan dengan standar/acuan pengelompokan yang sudah dibuat, maka dapat diukur berapa besar akurasinya. Hasil tipologi terpilih dilakukan pengujian dengan uji ragam dan evaluasi akurasi menggunakan prinsip matrik kesalahan (confusion matrix).

Uji ragam terhadap luas hutan rakyat dilakukan melalui uji dalam kelompok dan antar kelompok. Dimana yang dianggap baik jika ragam dalam kelompok kecil dan ragam antar kelompok besar. Dapat terlihat grafik pada Gambar 2 menunjukkan kedua uji tersebut. Pada Gambar 2a dapat dilihat bahwa uji ragam antar kelompok desain 1 sampai 4 relatif memiliki ragam dalam kelompok yang kecil dibanding desain 5 sampai 8. Sedangkan untuk uji ragam antar kelompok pada Gambar $2 b$, ragam yang terbesar adalah desain ke 2, 5, 7, dan 8 .

Dalam rangka menentukan desain yang teruji dengan baik dari ke delapan desain lewat dua uji ragam tersebut, maka dilakukan pengurangan antara uji ragam antar kelompok dengan uji ragam dalam kelompok, nilai selisih terbesar adalah yang memiliki nilai uji yang baik. Pada Tabel 7 diketahui selisih terbesar uji ini adalah pada desain jumlah 2 variabel dengan tiga kelompok, selanjutnya desain 2 variabel dengan

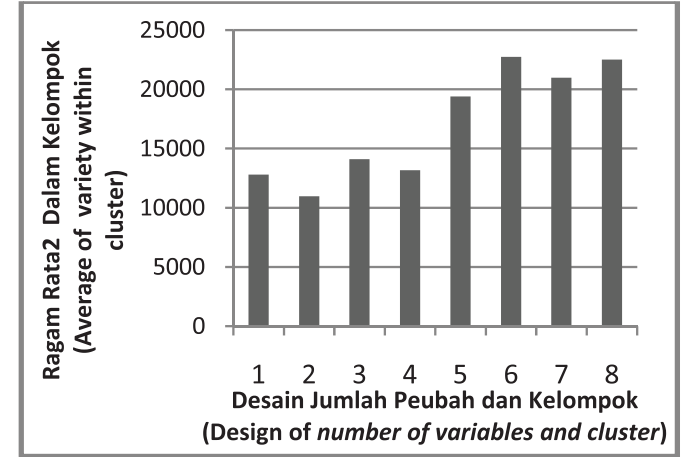

a. Ragam dalam kelompok (Within cluster variant)

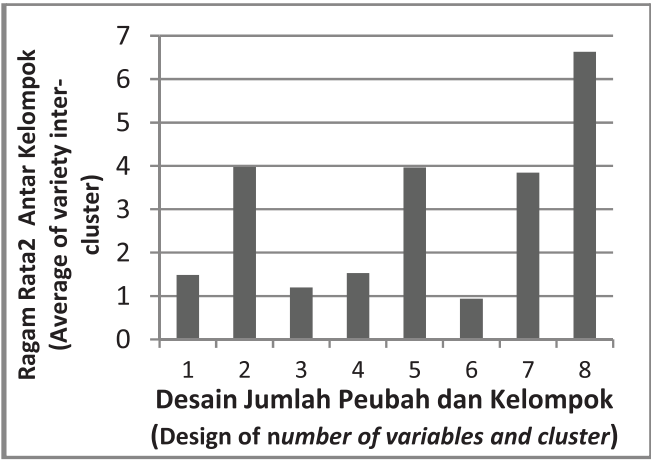

b. Ragam antar kelompok (Between cluster variant)

Keterangan (Remarks) :

1= 2 Variabel-2Kelp, 2= 2 Variabel-3 Kelp, $3=4$ Variabel-2 Kelp, 4= PC1234-2Kelp, 5= PC1234-3Kelp, 6= PC123-2Kelp, $7=$ PC123-3Kelp, $8=$ PC123-4Kelp

Gambar(Figure)2. Perbandingan Ragam dalam Kelompok dengan Ragam Antar Kelompok. (Comparison of whitin cluster and inter cluster variant) 
2 kelompok, dan yang ketiga desain dengan mengunakan analisis komponen utama dengan 4 KU yang membagi 2 kelompok.

Berdasarkan variabel yang digunakan maka, delapan desain yang dianalisis tiga desain menggunakan peubah asli sedangkan lima desain sudah menggunakan peubah PC yang diubah melalui analisis komponen utama (AKU). Metode gerombol (clustering analysis) menggunakan asumsi tidak ada multikolinieritas antar peubah yang digunakan. Dengan menggunakan peubah yang sudah melalui AKU dapat menghilangkan multikolinieritas tersebut. Tetapi menurut Santoso (2010), menyatakan batas kolinieritas tersebut masih dapat ditolerir untuk nilai korelasi dibawah 0,5.

Pada Tabel 8 dapat diketahui hasil evaluasi akurasi pada kedelapan desain terpilih. Diperoleh nilai akurasi rata-rata umum dan akurasi Kappa terbesar terdapat pada perlakuan desain PC1234 dengan 2 kelompok dengan nilai masing-masing $64 \%$ dan $27 \%$. Desain kedua yang terbaik adalah 2 variabel dengan 2 kelompok dengan nilai akuarasi umum sebesar $63 \%$ dan akurasi Kappa sebesar 26\%. Ini menandakan bahwa desain tersebut yang paling akurat dalam menduga kelompok desa berdasarkan luas hutan rakyat.

Tabel(Table) 7. Ragam rata-rata antar kelompok dan dalam kelompok (Average variety of inter and within clusters)

\begin{tabular}{|c|c|c|c|c|c|c|c|c|}
\hline \multirow[b]{2}{*}{$\begin{array}{l}\text { Ragam } \\
\text { Rata-Rata } \\
\text { (Average } \\
\text { variant) }\end{array}$} & \multicolumn{8}{|c|}{ Desain Jumlah Variabel（Design of number of variables) } \\
\hline & $\begin{array}{c}2 \\
\text { Variabel } \\
-2 \text { Kelp }\end{array}$ & $\begin{array}{l}2 \text { Variabel } \\
-3 \text { Kelp }\end{array}$ & $\begin{array}{l}4 \text { Variabel } \\
-2 \text { Kelp }\end{array}$ & $\begin{array}{l}\text { PC1234 - } \\
2 \text { Kelp }\end{array}$ & $\begin{array}{l}\text { PC1234 - } \\
3 \text { Kelp }\end{array}$ & $\begin{array}{l}\text { PC123 - } \\
2 \text { Kelp }\end{array}$ & $\begin{array}{l}\text { PC123- } \\
3 \text { Kelp }\end{array}$ & $\begin{array}{l}\text { PC123 - } \\
4 \text { Kelp }\end{array}$ \\
\hline $\begin{array}{l}\text { Antar } \\
\text { Kelompok } \\
\text { (Between- } \\
\text { cluster) (A) }\end{array}$ & 1,485 & 3,971 & 1,196 & 1,532 & 3,963 & 0,940 & 3,846 & 6,632 \\
\hline $\begin{array}{l}\text { Dalam } \\
\text { Kelompok } \\
\text { (Within } \\
\text { cluster) (B) }\end{array}$ & $\begin{array}{r}12798,24 \\
3 \\
\end{array}$ & $\begin{array}{r}10971,44 \\
4 \\
\end{array}$ & $\begin{array}{r}14097,17 \\
6 \\
\end{array}$ & $\begin{array}{r}13171,59 \\
0 \\
\end{array}$ & 19388,301 & 22740,072 & 20972,55 & 22500,55 \\
\hline $\begin{array}{l}\text { Selisih } \\
\text { (differen-ce) } \\
\text { (A-B) }\end{array}$ & $\begin{array}{r}-- \\
12796,75 \\
7\end{array}$ & $\begin{array}{r}- \\
10967,47 \\
3\end{array}$ & $\begin{array}{r}- \\
14095,98 \\
0\end{array}$ & $\begin{array}{r}- \\
13170,05 \\
7\end{array}$ & $\begin{array}{r}- \\
19384,338\end{array}$ & $-22739,132$ & 20968,706 & 22493,920 \\
\hline Rangking & & & & & & & & 7 \\
\hline
\end{tabular}

Tabel (Table) 8. Nilai akurasi rata-rata umum dan akurasi Kappa (Value of overall accuracy and Kappa accuracy)

\begin{tabular}{|c|l|c|c|}
\hline \multirow{2}{*}{ No. } & \multirow{2}{*}{$\begin{array}{c}\text { Desain jumlah Variabel } \\
\text { (number of variables design) }\end{array}$} & \multicolumn{2}{|c|}{ Akurasi (Accuracy) } \\
\cline { 3 - 4 } & & $\begin{array}{c}\text { Rata-Rata Umum } \\
\text { (Overall) }\end{array}$ & $\begin{array}{c}\text { Kappa } \\
\text { (Kappa) }\end{array}$ \\
\hline 1. & 2 Variabel-2 kelompok & 63,393 & 26,363 \\
\hline 2. & 2 Variabel-3 kelompok & 46,429 & 17,482 \\
\hline 3. & 4 Variabel-2 kelompok & 60,714 & 21,026 \\
\hline 4. & PC1234-2 kelompok & 63,988 & 27,633 \\
\hline 5 & PC1234-3 kelompok & 40,179 & 13,932 \\
\hline 6 & PC123-2 kelompok & 50,595 & 1,650 \\
\hline 7 & PC123-3 kelompok & 40,476 & 14,271 \\
\hline 8 & PC123-4 kelompok & 27,083 & 6,015 \\
\hline
\end{tabular}




\section{Karakteristik dan Arah Pengembangan Tipologi}

Pada proses akurasi terdapat dua desain yang memiliki akurasi yang baik, yaitu desain dengan mengunakan PC1234 dengan nilai akurasi sebesar $64 \%$ dan desain dengan 2 variabel (rasio kelerengan dan kerapatan jalan) dengan nilai akurasi sebesar 63\%. Sebaran pengelom-pokan desa berdasarkan desain tersebut dapat dilihat pada Gambar 3. Berdasarkan desain PC1234 terlihat dugaan wilayah Kabupaten Ciamis memiliki 70\%

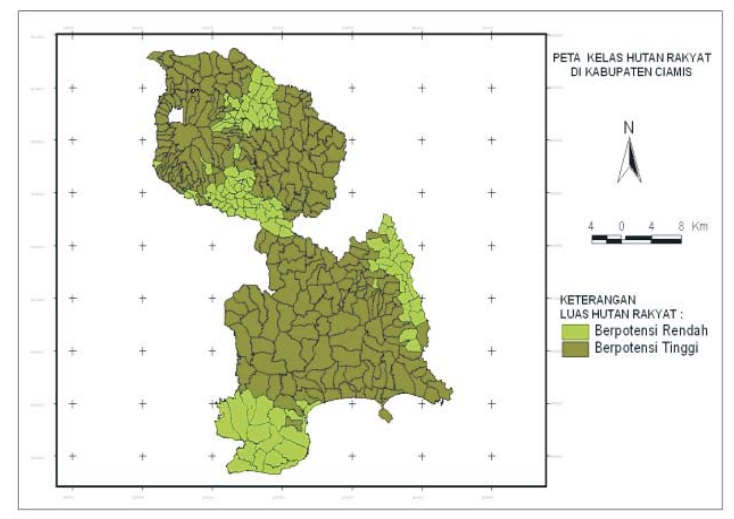

(a) Pc1234- 2 kelompok daerah yang memiliki potensi pengembangan hutan rakyat yang besar. Sedangkan berdasarkan desain 2 variabel menduga sebanyak $74 \%$ wilayah Kabupaten Ciamis merupakan daerah yang memiliki potensi pengembangan yang besar. Potensi pengem-bangan hutan rakyat disini dilihat dari besarnya luasan hutan rakyat di dalam suatu desa. Diharapkan dengan memiliki luas hutan rakyat yang besar merupakan salah suatu peluang untuk mencapai pengelolaan hutan rakyat yang menguntungkan dan efisien.

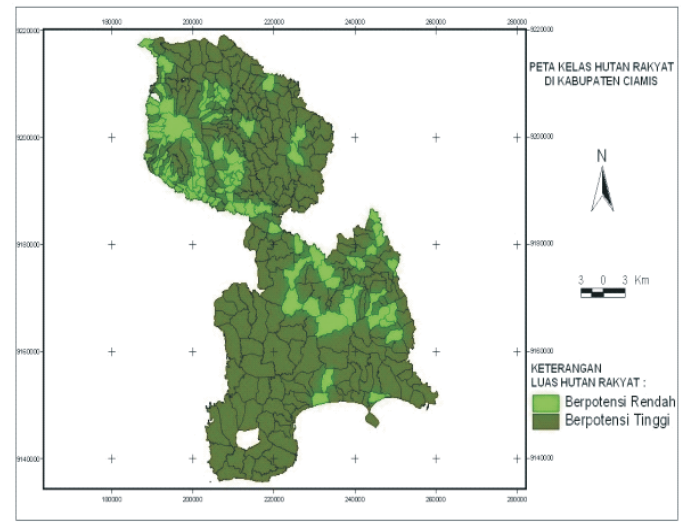

(b) 2 variabel-2 kelompok

Gambar(Figure) 3. Pengelompokan berdasarkan desain (a) PC1234 dan (b) 2 variabel (Grouping based on design (a) PC1234 and (b) 2 variable)

Dari Gambar 3 dapat dilihat bahwa sebaran yang dihasilkan dengan desain PC1234 terlihat lebih kompak dan sehamparan dibanding sebaran yang dihasilkan desain 2 variabel. Untuk membentuk satu unit pengelolaan lebih mudah ketika wilayah yang akan digabungkan berdekatan secara spasial. Tetapi jika unit pengelolaan tersebut berupa desa tentunya dapat berdiri sendiri secara individual ketika potensinya besar.

Tabel (Table ) 9. Karakteristik dan arah pengembangan setiap tipologi (Characteristics and direction of development of each typology)

\begin{tabular}{|c|l|l|c|c|}
\hline Tipologi & \multicolumn{1}{|c|}{$\begin{array}{c}\text { Karakteristik } \\
\text { Wilayah }\end{array}$} & \multicolumn{1}{|c|}{$\begin{array}{c}\text { Arah Pengembangan } \\
\text { (Development direction) }\end{array}$} & \multicolumn{2}{|c|}{$\begin{array}{c}\text { Jumlah Desa } \\
\text { (Village numbe })\end{array}$} \\
\cline { 3 - 5 } & I & $\begin{array}{l}\text { Merupakan wilayah-wilayah } \\
\text { desa dimana penggunaan }\end{array}$ & $\begin{array}{l}\text { Pesain } \\
\text { PC1234 }\end{array}$ & $\begin{array}{c}\text { Desain 2 } \\
\text { Variabel }\end{array}$ \\
\hline $\begin{array}{l}\text { lahannya tidak didominasi } \\
\text { mengarah ke bidang di luar } \\
\text { hutan rakyat. Terdapat } \\
\text { kondisi-kondisi yang kurang } \\
\text { memungkinkan untuk } \\
\text { berkembangnya hutan rakyat }\end{array}$ & $\begin{array}{l}\text { bertahan untuk kegiatan hutan } \\
\text { rakyat sebaiknya perlu } \\
\text { penggabungan wilayah yang } \\
\text { lebih besar untuk menjadikan }\end{array}$ & 101 & 87 \\
\hline
\end{tabular}


Tabel(Table) 9. Lanjutan(Continued)

\begin{tabular}{|c|c|c|c|c|}
\hline \multirow{2}{*}{$\begin{array}{l}\text { Tipologi } \\
\text { Wilayah }\end{array}$} & \multirow{2}{*}{$\begin{array}{l}\text { Karakteristik } \\
\text { (Characteristic) }\end{array}$} & \multirow{2}{*}{$\begin{array}{c}\text { Arah Pengembangan } \\
\text { (Development direction) }\end{array}$} & \multicolumn{2}{|c|}{$\begin{array}{c}\text { Jumlah Desa } \\
\text { (Village numbe) }\end{array}$} \\
\hline & & & $\begin{array}{c}\text { Desain } \\
\text { PC1234 }\end{array}$ & $\begin{array}{l}\text { Desain 2 } \\
\text { Variabel }\end{array}$ \\
\hline & $\begin{array}{l}\text { secara biofisik ditambah } \\
\text { aspek sosial ekonomi. }\end{array}$ & $\begin{array}{l}\text { suatu unit pengelolaan yang } \\
\text { lestari. }\end{array}$ & & \\
\hline II & $\begin{array}{l}\text { Merupakan wilayah-wilayah } \\
\text { desa yang memiliki potensi } \\
\text { hutan rakyat yang besar. } \\
\text { Faktor-faktor biofisik dan } \\
\text { ditambah dengan sosial } \\
\text { ekonominya mendukung } \\
\text { untuk berkembangnya } \\
\text { pengelolaaan hutan rakyat di } \\
\text { wilayah ini. }\end{array}$ & $\begin{array}{l}\text { Perlu penanganan yang lebih } \\
\text { profesional untuk mengelola } \\
\text { potensi hutan rakyat dari } \\
\text { berbagai pihak, baik petani, } \\
\text { kelompok tani, pemerintah, } \\
\text { lembaga masyarakat dan } \\
\text { lainnya. Perlu dibentuk } \\
\text { wadah / unit pengelolaan } \\
\text { hutan rakyat agar terjadi } \\
\text { sistem yang menjamin } \\
\text { kelestarian. }\end{array}$ & 235 & 249 \\
\hline
\end{tabular}

Desa yang dianggap berpotensi tinggi adalah yang mempunyai nilai lebih besar dari rata-rata luas hutan rakyat di Ciamis, yaitu berkisar $58 \mathrm{Ha}$ setiap desa. Jumlah desa berpotensi tinggi hasil dugaan desain penelitian ini lebih besar dari nilai acuan sebenarnya. Terdapat beberapa hal yang memungkinkan perbedaaan ini, salah satunya karena secara fakta kondisi biofisik dan sosial ekonomi mendukung untuk berkembangnya hutan rakyat, tetapi saat ini bisa jadi yang berkembang adalah tanaman non kehutananan seperti kelapa, cengkeh, dan lainnya.

\section{KESIMPULAN DAN SARAN}

\section{A. Kesimpulan}

1. Tipologi yang terbentuk ada dua, yaitu tipologi wilayah yang berpotensi untuk berkembangnya hutan rakyat dan wilayah yang tidak berpotensi berkembang hutan rakyat. Desain metode yang digunakan menggunakan desain 4 komponen utama (Pc1234). Hasil pengujian memiliki keragaman dalam kelompok dan antar kelompok yang baik dan nilai akurasi yang lebih besar dari yang lain, yaitu akurasi ratarata umum sebesar $64 \%$. Selain itu desain kedua yang teruji adalah menggunakan desain 2 variabel, yaitu rasio kelerengan lahan dan kerapatan jalan dengan akurasi rata-rata $63 \%$.
2. Terdapat delapan variabel yang berkorelasi nyata dengan luas hutan rakyat di suatu desa, tiga variabel terbesar adalah rasio kelerengan lahan, kerapatan jalan, dan rasio penggunaan lahan bukan sawah. Kelima variabel lainnya berurutan berdasarkan besarnya korelasi dengan luas hutan rakyat adalah jarak ke hutan negara, rasio umur produktif, kepadatan penduduk, kemampuan lahan, dan rasio rumah permanen.

\section{B. Saran}

Berdasarkan hasil penelitian ini, maka disarankan untuk menentukan arah pengembangan pengelolaan hutan rakyat suatu wilayah perlu pertimbangkan variabel-variabel yang berpengaruh dalam pengembangan potensi hutan rakyat seperti di penelitian ini. Agar perencanaan pengelolaan yang diterapkan dapat mewakili karakteristik masing-masing wilayahnya.

\section{DAFTAR PUSTAKA}

Arsyad, S. 1989. Konservasi Tanah dan Air. IPB. Bogor.

Awang, S.A, H Santosa, W.T Widayanti, Y Nugroho, Kustomo, Sapardiono. 2001. Gurat Hutan Rakyat. Debut Press, Yogyakarta.

Awang, S.A, E.B Wiyono, dan S. Sadiyo. 2007. Unit Manajemen Hutan Rakyat: Proses 
Konstruksi Pengetahuan Lokal. Banyumili Art Network bekerjasama dengan Pusat Kajian Hutan Rakyat. Fakultas Kehutanan UGM. Yogyakarta.

Bliss, J.C. 2003. Sustaining Family Forest in Rural Landscapes: Rationale, Chalenges, and an Illustration from Oregon, USA. Small-scale Forest Economics, Management and Policy, 2(1): $1-8,2003$.

Davis, L.S, K.N .Johnson, P.S. Bettinger, and T.E. Howard. 2001. Forest Management: To Sustain Ecological, Economic, and Social Values. Fourth Edition. McGrawHill Companies, Inc. New York.

Dillon, W.R dan M. Goldstein. 1984. Multivariate Analysis, Method and Applications. John Wiley \& Sons, New York.

Haeruman, H., R. Abidin, Hardjanto, dan E. Suhendang. 1991. Studi Kemungkinan Pengembangan Konservasi Lahan melalui Hutan Rakyat. Fakultas Kehutanan IPB, Bogor.

Hardjanto, 2003. Keragaan dan Pengembangan Usaha Kayu Rakyat di Pulau Jawa [disertasi]. Bogor: Program Pascasarjana, Institut Pertanian Bogor.
Harrison, S., J. Herbohn, dan A. Niskanen. 2002. Non Industrial, Smallholder, Small-scale and Family Forestry: What's in a Name? Small-scale Forest Economic, Management and Policy, 1(1): 1-11.

Jaya, I.N.S. 2006. Analisis Citra Digital : Perspektif Penginderaan Jauh Untuk Pengelolaan Sumberdaya Alam. Fakultas Kehutanan Institut Pertanian Bogor. Bogor.

Mindawati, N., A. Widiarti, dan B. Rustaman. 2006. Review Hasil Penelitian : Hutan Rakyat. Pusat Penelitian dan Pengembangan Hutan Tanaman, Badan Penelitian dan Pengembangan Kehutanan. Bogor.

Rahmadia, E. 2003. Analisis Tipologi dan Pengembangan Desa-Desa Pesisisr Kota Bandar Lampung. Tesis. Program Pascasarjana. Institut Pertanian Bogor.

Santoso, S. 2010. Statistik Multivariat, Konsep dan aplikasi dengan SPSS. PT Elex Media Komputindo Kompas Gramedia. Jakarta

Suharjito, D. 2000. Hutan Rakyat di Jawa: Perannya dalam Perekonomian Desa. Program Penelitian dan Pengembangan Kehutanan Masyarakat Fakultas Kehutanan IPB, Bogor. 